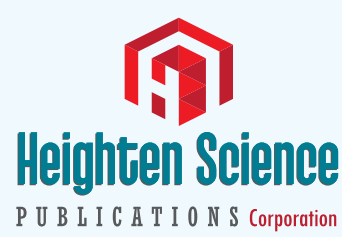

ISSN

2639-9946
Review Article

\section{Herbal approach for obesity management}

\author{
Preeti Singh* \\ Researcher, Trans-Disciplinary University, Bengaluru, Karnataka, India
}

*Address for Correspondence: Preeti Singh, Researcher, Trans-Disciplinary University, Bengaluru, Karnataka, India, Email:

Preeti.singh@tdu.edu.in

Submitted: 09 November 2018

Approved: 29 November 2018

Published: 30 November 2018

Copyright: (c) 2018 Singh P. This is an open access article distributed under the Creative Commons Attribution License, which permits unrestricted use, distribution, and reproduction in any medium, provided the original work is properly cited

Keywords: Morbidity; Ayurveda; Obesity; Literature survey; Medicinal plants; Herbal products; Weight management

Check for updates

\section{Abstract}

Heftiness, a mind boggling interchange among ecological and hereditary factors and is related with critical horribleness and mortality. Utilization of herbs for the administration of heftiness in the ongoing occasions is pulling in consideration. A web and manual based writing overview was led to survey the measure of data accessible on the natural items for weight administration. Customary writing, PubMed, Scopus, Google researcher databases were screened up to February 2012. The pursuit words were "stoutness", "home grown medication/items/separates", "restorative plants", "customary drug", "Ayurvedic prescription" without narrowing/constraining looking words or components. Distributions just with edited compositions/full articles and books were inspected in the pursuit. In light of the accessible writing, for huge numbers of the natural and weight reduction items, there is minimal distributed data and there have been no clinical preliminaries or the level of proof is restricted. Our writing study additionally demonstrated that these home grown items fall under an adequate level of proof or with no scientific foundation by any stretch of the imagination, or they have a logical discerning however not to an acknowledgment level. Endeavors were made in the audit to characterize the highlights of conceivable natural weight reduction item. A perfect home grown enemy of stoutness item ought to diminish the weight by $10 \%$ over fake treatment of treatment by demonstrating a proof of change of bio markers like blood pres-beyond any doubt, lipids and glycemia with no reactions.

\section{Introduction}

Collection of fat over the restrain prompted sick/antagonistic effect in the body known as heftiness. Weight file (BMI) is a list of weight-for-tallness that is ordinarily used to arrange overweight and heftiness in grown-ups. The World Wellbeing Association (Definition's identity: 1) A BMI more prominent than or equivalent to 25 is overweight and, 2) A BMI more prominent than or equivalent to 30 is heftiness. BMI gives valuable populace level proportion of overweight and obesity as it is the equivalent for both genders and for all periods of grown-ups. Be that as it may, it ought to be considered as harsh guidance since it may not compare to a similar level of largeness in various people.

Corpulence and overweight happens because of lopsidedness between calories expended and calories used. Comprehensively, there have been two purposes behind overweight and stoutness: 1) an expanded admission of vitality thick nourishment that are high in fat, salt and sugars yet low in vitamins, minerals and different micronutrients; and, 2) a decline in physical action because of the undeniably inactive nature of numerous types of work, changing methods of transportation, and expanding urbanization $[1,2]$. Changes in dietary and physical movement designs are frequently results from inactive way of life, not sleeping enough, endocrine disruptions, for example, a few nourishment that meddle with lipid digestion, medications that make patients put on weight, therapeutic and mental disease and irresistible operators.

Overweight and stoutness are the fifth driving danger for worldwide passing. Somewhere around, 2.8 million grown-ups kick the bucket every year because of being 
overweight or large. Also, $44 \%$ of the diabetes load, $23 \%$ of the ischemic heart disease trouble and somewhere in the range of $7 \%$ and $41 \%$ of certain tumor troubles are owing to overweight and stoutness. WHO worldwide assessments for the year 2008, announced 1.5 billion individuals were overweight, of these, more than 200 million men and almost 300 million ladies were large. By and large, more than one of every ten of the world's grown-up populace was corpulent $[1,3]$.

In 2010, around 43 million youngsters under five were overweight. Overweight and heftiness are presently on the ascent in low and center wage nations, especially in urban settings. Near 35 million overweight kids are living in creating nations and 8 million in created nations. Youth weight is related with a higher shot of heftiness, sudden passing and handicap in adulthood. In any case, notwithstanding expanded future dangers, corpulent kids encounter breathing challenges, expanded danger of cracks, hypertension, cardiovascular infections and mental impacts [4].

Overweight and corpulence are connected to a greater number of passing worldwide than underweight. For a model, $65 \%$ of the total populace live in nations where overweight and weight murder a greater number of individuals than underweight (this includes all high-salary and most center wage coun-attempts). Weight is a noteworthy wellbeing risk. The additional weight puts included pressure all aspects of person's body. Individuals with corpulence are in danger for these medical issues: Bone and joint issues because of additional weight puts strain on the bones and joints. This can prompt osteoarthritis, an ailment that causes joint agony and solidness, gallstones and liver issues, heart assault from coronary illness, congestive heart disappointment, and stroke, high blood cholesterol and triglycerides (dislipidemia or high blood fats), (hypertension), high (glucose) or diabetes, halting breathing amid (rest apnea). This can cause daytime exhaustion or sleepiness, poor consideration, and issues at work.

Heftiness is perceived as the most critical hazard factor for sort 2 diabetes. Corpulence, specifically intra abdominal adiposity, is related with expanded free unsaturated fat (FFA) fixations in blood plasma which practice a noteworthy negative impact on insulin affectability in the two muscles and liver. Other than insulin opposition, damaged insulin emission is an essential for the advancement of sort 2 diabetes. Both lipotoxicity and glucotoxicity may start and empower an endless loop tried and true for the metabolic disability. Diabetes happens as a late marvel in heftiness and is gone before by long periods of impeded glucose resilience. The movement to diabetes is shown by a failure of the B cells of pancreatic langerhans to primary train its high rate of insulin emission in light of glucose in face of insulin obstruction [5]. The halfway reversibility of the development of heftiness towards diabetes is all around exhibited today by way of life changes and multidisciplinary health improvement plans [6]. Nature is improved with plant riches for every living animal, which have medicinal temperance's [7]. Hostile to diabetic action has been re-ported in numerous plants amid the most recent few years. In addition, their component of activity varies from that of insulin in that they seem to go about as enemies of metabolites, capable of obstructing the pathway of oxidation of unsaturated fats. Around 343 plants of the world have been tried for the blood glucose which discovered bringing down impact in the lab tests. Of them, 158 species are professed to be utilized in conventional framework on Indian prescription [8].

The central objective of corpulence treatment is to keep up solid weight. The treatment technique to be embraced frequently relies upon the favored decision of an individual experiencing treatment and in addition the level of heftiness. Normal treatment measures incorporate the accompanying methods, dietary changes, exercise and action, conduct change, and remedy weight reduction medicines and weight reduction medical procedure [2]. 
The favored treatment methodology for weight reduction is dieting and physical exercise. Yet, because of occupied timetables and stationary way of life follow-up the initial two strategies never is by all accounts rehearsed in a standard way. Then again weight reduction medical procedure comes up short on the alternative considering the cost included. There is a progressive move towards an expansion utilization of medications. Medications are pharmacological operators that decrease or control weight. These medications adjust one of the major procedures of the human body, weight control, by changing craving, digestion, or retention of calories. Just a single enemy of corpulence medications orlistat is right now affirmed by the FDA for long haul utilizes. It diminishes intestinal fat retention by hindering pancreatic lipase [3]. Rimonabant, a second medication regularly alluded to as "the munchies", had been endorsed in Europe for the treatment of weight however has not gotten endorsement in the Assembled States and Canada because of wellbeing concerns [9]. Sibutramine, which follows up on the mind to hinder deactivation of the synapses, along these lines de-wrinkling craving was pulled back from the Unified States and Canadian markets in October 2010 due to cardio-vascular symptoms [6]. Due to potential reactions, it is suggested that enemy of corpulence tranquilizes just be pre-scribed for stoutness where it is trusted that the advantages of the treatment exceed its hazard [10].

The utilization of allopathic and pharmacological medications has turned into a mainstream intends to conquer overabundance weight gain [11]. While these medications for the most part are viable, serious unfavorable toxicities may confine their general helpfulness $[12,13]$. A nutritious based mediation is being hailed as a cheap choice to help weight reduction, and weight administration [14]. Restorative home grown enhancements are being widely used because of their viability in overseeing numerous endless issues. They are cost effective, and apply less to no lethal reactions in correlation with numerous synthetically blended medications [15]. Accordingly, late primer reports proposed that herbs with a long history of utilization and other regular substances less inclined to deliver serious lethality may be compelling in decreasing craving and advancing noteworthy weight reduction are empowering [16].

\section{Obesity and psychiatric co-morbidity}

The proof for the exchange between certain dysfunctional behaviors (voraciously consuming food, nervousness, and temperament issue) and corpulence is bidirectional [17]. Different demographical bunches recommend that social or social elements may direct or intercede the relationship among heftiness and state of mind issue. Populace with a mental issue is at higher hazard for overweight and heftiness than solid ones [18-20]. At present there is no reasonable connection finished up between obesity and psychopathology, and whether the conceivable psychological clutters are a reason or a result of corpulence has not yet been elucidated either [21]. Studies do depicts that specific mental scatters appear to be more typical in corpulent individuals, for example, despondency, anxiety, substance misuse, and so forth., in spite of the fact that the bearing of the informative connection isn't clear; in addition, the contrary outcome has additionally been discovered [22]. Besides, there are thinks about which decide high pervasiveness rates of mental issue in fat patients looking for treatment, proposing the mental assessment of hefty patients as a normal practice [23]. The insignificant confirmations of likely co bleak psychopathology imply that the specialist must consider its as-assessment in heftiness cases, and incorporate an arrangement for a psychiatric or potentially mental helpful mediation. Over the previous decade, there has been an extraordinary increment in the utilization of correlative treatment, for example, home grown remekicks the bucket for soothing the mental side effects of stoutness and the related morbidities [21,22]. Lee et al. has suggested the utilization of $\mathrm{Ob}-\mathrm{X}$, a blend of three herbs Melissa officinalis L. (Labiatae), Morus alba L. (Moraceae), and Artemisia capillaris Thunb. (Compositae) for controlling hyperlipidemia [23].

\section{Herbs recommended for obesity}

Confirmations are developing to help that an expanding utilization of herbs are 
viable system for heftiness control and weight administration. Utilization of plants and plant items can possibly keep the expanding prevalence of metabolic disorder in charge. There are few medications in the market to avert/oversee weight however there are the costs, adequacy and symptoms to consider. For quite a long time individuals over the nations have been utilizing normal items as plant based dietary enhancements for weight control [24].

\section{Traditional medicine and obesity}

Ayurveda (Ayur = life, Veda = learning), or, in other words "Life", started from the Vedic occasions and is a piece of all encompassing human services framework. The main wellspring of old Indian Aryan culture and drug are the four Vedas that are generally accepted to be uncovered to the sages by Brahma (the maker) somewhere in the range of 6000 years previously Christian period. Ayurveda's essential accentuation is on preservation and advancement of wellbeing, it likewise gives treatment to sickness. Numerous unwanted constitutions (around eight) in the body are said in "Charaka Samhita", a real wellspring of ayurveda. Heftiness or "Medoroga" is one among them. It is said that it is relatively simple to encourage an underweight individual, instead of an overweight individual. The overweight issue can be because of a real increment in the fat part (Meda Dhatu), or it very well may be because of breaking down. These, in like manner, will require diverse methodologies. In not very many cases it very well may be an off-shoot of other metabolic clutters. We have inspected the accessible ayurvedic/customary writings books [25-28] for hunting plants which are shown down corpulence. The point by point rundown of plants has been delineated in table 1 .

\begin{tabular}{|c|c|c|}
\hline Botanical name & Sanskrit/official name & Part(s) used \\
\hline Acacia arabica & Babbula & Gum, bark, leaf, fruit-pods \\
\hline Acacia catechu & Khadira & bark, heartwood, flower \\
\hline Achyranthus aspera & Apamarga & Root, seed, leaf, whole plant \\
\hline Aconitum heterophyllum & Ativisha & Root, rhizome \\
\hline Acorus calamus & Vacha & Rhizome \\
\hline Adathoda vasica & Vasa & Leaf, root, flower \\
\hline Aloe vera & Kumari & Leaf, root \\
\hline Alstonia scholaris & Saptaparna & Bark, latex, flower \\
\hline Ananas comosus & Ananas & Fruit \\
\hline Anthocephalus chinensis & Kadamba & Bark, leaf, fruit, root \\
\hline Azadirachta indica & Nimba & All parts \\
\hline Berberis aristata & Daruharidra & Root, stem, fruit \\
\hline Betula utilis & Burja & Bark, nodes \\
\hline Calatropis gigantea & Arka & Root, bark, flower, leaf, latex, seed \\
\hline Calicarpa macrophylla & Priyangu & Flower, leaf \\
\hline Capsicum annuum & Kutavira & Fruit \\
\hline Cassia tora & Chakramardha & Seed, leaf, root \\
\hline Cedrus deodara & Devadaru & Heartwood oil \\
\hline Cinnamomum zeylanicum & Twak & Bark, leaf, oil \\
\hline Cissampelos pareira & Patha & Root, stem \\
\hline Clerodendrum phlomidis & Agnimantha & Root, bark, leaf \\
\hline Cocus nucifera & Narikela & Fruit, flower, oil, root \\
\hline Commiphora Mukul & Guggulu & Gum-resin \\
\hline Coriandum sativum & Dhanyaka & Whole plant, leaf, fruit \\
\hline Costus speciosus & Kebuka & Rhizome \\
\hline Cuminum cyminium & Jeeraka & Seed \\
\hline Curcuma longa & Haridra & Rhizome \\
\hline Desmostachya bipinnata & Kusa & Root \\
\hline Dolichos biflorus & Kulatta & Seed \\
\hline Embelia ribes & Vidanga & Fruit \\
\hline Emblica officinalis & Amalaki & Fruit \\
\hline Euphobia nerifolia & Snuhi & Latex, stem, leaf, root \\
\hline Ferula nortex & Hingu & Oleo-gum resin \\
\hline Ficus Glomerata & Udumbara & Bark, fruit, latex \\
\hline
\end{tabular}




\section{Modern literature and obesity}

An immense number of home grown enhancements are right now pre-sent in the market for the administration of weight, al-however not every one of them have a similar impact, reason being, supplements focusing on various particles in this way following one of a kind component of activity changing totally from the other. The essential standard fundamental the method of activity of hostile to corpulence supplements is managing the vitality balance in the body, or, in other words between vitality admission and consumption. For the accommodation of clarifying/ understanding distinctive investigations pursue different methodologies of classifying the component, either based on the impact of the medication on sensory system or the impact of an enhancement on physiological capacities/conduct.

Sufficient of audit on against weight supplements have classified their instrument of activity fundamentally based on the action they manage. For a model, Yun et al. [29] ordered the system of hostile to stoutness activity of characteristic enhancements based on the impact they deliver 1) diminished lipid assimilation, 2) diminished vitality admission, 3) expanded vitality consumption, 4) diminished preadipocyte separation and expansion, or 5) diminished lipogenesis and expanded lipolysis. For covering the more extensive territory and also for the comfort of comprehension, Saper et al. [30] characterized the instrument of activity of hostile to stoutness item based on: 1) Increment vitality consumption, 2) Tweak of starch digestion, 3) Increment satiety, 4) Increment fat oxidation or diminished fat amalgamation, 5) Square dietary fat retention, 6) Expanded water end, 7) Improve state of mind, 8) Incidental and unspecified.

We saw that there is plenty of writing on the component of activity of engineered mixes alongside persuading number regarding clinical investigations to stand its security, however consistent withdrawal of the real medications (USFDA endorsed) because of the evil impacts [31], cleared a route for the development of dietary enhancements as a protected choice to fix weight. In the meantime the accessible writing on component of activity of medications will decode the possible particles and the sub-atomic system by which the dynamic phyto mixes follow up on. Like a medication, supplements likewise can act incidentally, halfway or in mix (incidentally and focal) on the receptors of the sensory system, consequently overseeing hunger, digestion (lipid and starch) or caloric ingestion.

In the present audit, we overviewed the common items with hostile to weight potential and explored the logical information, including exploratory procedures, dynamic segments, and instruments of activity against heftiness. We ordered the system of activity of herbs viz., 1) Incidentally acting and 2) Halfway acting.

Peripherally Acting Mechanism: Substances acting incidentally, intervene their belongings by lessening the calorie assimilation in the gastrointestinal framework or by influencing metabolic as well as control frameworks outside the focal sensory system (CNS). One of the best approaches to decrease vitality admission is through gastrointestinal systems, for example, supplements processing and assimilation [32].

Lipase Inhibition: Dietary fat isn't straightforwardly consumed by the digestive tract except if the fat has been subjected to the activity of pancreatic lipase. Consequently, pancreatic lipase is a standout amongst the most generally examined components for deciding normal nudge potential adequacy as hostile to corpulence operators [32]. Supplement acts in the gut lumen by framing a covalent bond with the dynamic serine site of gastric and pancreatic lipases. By shaping the covalent bond, it hinders these lipases from hydrolyzing the ingested fat into absorbable free unsaturated fats and monoglycerides. The diminished abdominal muscle sorption of ingested fat prompts a generally speaking diminished caloric retention, thusly prompting weight reduction [33]. 
A wide assortment of plants has pancreatic lipase inhibitory impacts, including Panax japonicus [34], Platycodi radix [35], Salacia reticulata [36], Nelumbo nucifera [37]. These pancreatic lipase inhibitory phytochemicals incorporate principally saponins, polyphenols, flavonoids, and caffeine [38-40]. The most concentrated normal wellsprings of pancreatic lipase inhibitors are gotten from various kinds of tea (e.g. green, oolong, and dark tea). An altogether unique kind of polyphenols detached from tea leaves, demonstrated solid inhibitory action towards pancreatic lipase [41-43]. These polyphenols require galloyl moieties inside their synthetic structures and additionally polymerization of their flavan-3-ols for improved pancreatic lipase hindrance [42].

Adipogenesis down Regulation: Vitality equalization and lipid homeostasis is kept up in the body by specific cells called as adipocytes. Adipocytes fundamentally store triglycerides and discharge them as free unsaturated fat with the difference in vitality request in the body [44].

Adipogenesis is an unpredictable procedure managed by the statement of a few hundred qualities. The essential adipogenic interpretation factors associated with adipocyte separation has a place with the peroxisome proliferator activator receptor (PPAR), C/EBP, and sterol administrative component restricting protein (SREBP) families. PPAR- $\gamma$ articulation amid separation is an imperative occasion in adipogenesis process in fat cells [45]. Polyunsaturated unsaturated fats (PUFAs), a fundamental parts of the phospholipids of cell films and goes about as a flag transducer managing adipocyte particular quality articulation engaged with lipid digestion and adipogenesis [46]. Different phytochemicals like quercetin, kaempferol and catechin and dietary flavonoids found in vegetables, natural products, green tea and herbs are accounted for to down-manage the adipogenesis related transcriptional factors PPAR- $\gamma, \mathrm{C} / \mathrm{EBP}-\alpha$ and SREBP-1 and to repress adipocyte separation amid the beginning time. Tea catechins and epigallocatech in gallate (EGCG) diminished the heaviness of subject fat tissue [47-50].

Notwithstanding indicating inhibitory movement against adipocyte separation, a few normally happening mixes have shown apoptotic consequences for developing preadipocytes, e.g. phytochemicals, for example, esculetin, resveratrol, quercetin, genistein, capsaicin, and conjugated linoleic acids prompted apoptosis of developing 3T3-L1 preadipocytes through concealment of ERK1/2 phosphorylation, enactment of the mitochondrial pathway, AMPK actuation, or hostile to oxidant action [51-55]. Sirtuin 1 is another objective particle for hostile to stoutness treatment. De-wrinkled adipogenesis due to resveratrol related with expanded articulation of Sirtuin1, which advances fat preparation by subduing PPARc [56,57].

Thermogenesis: Exorbitant adiposity results from a lopsidedness in vitality homeostasis because of over the top nourishment admission are not adjusted by expanded vitality use [58,59]. To direct body weight and vitality consumption, warm blooded animalian BAT (dark colored fat tissues) sets up nonshivering thermogenesis through scattering of overabundance vitality as warmth [60]. BAT assumes a vital job in corpulence control by controlling vitality balance.

The key player in this procedure is UCP (Mitochondrial uncoupling protein), which releases the proton inclination produced in oxidative phosphorylation, in this way disseminating vitality as warmth. In this manner, hunting down substances that upregulate UCP1 quality articulation might be a commendable procedure for accomplishing weight control through expanded vitality consumption [61]. Yoon et al. has demonstrated that ethanolic concentrate of Solanum tuberosum, can actuate the statement of UCP3 in BAT and the liver and essentially decreased fat weight in HFD fed rats [62]. Various normally happening mixes have been proposed as medications for weight reduction by means of upgraded vitality expenditure, including caffeine $[63,64]$ and capsaicin $[57,65]$.

Lipid Metabolism: The pharmacological focusing of lipolysis can be visualized in two diverse ways. The main procedure involves invigorating triglyceride hydrolysis 
with the end goal to lessen fat stores, along these lines fighting weight. This choice requires the related oxidation of the recently discharged unsaturated fats and prompted the improvement of the b3-adrenergic agonists [66]. A few models of the regular mixes associated with b3-adrenergic receptor initiation are the different flavonoids in the leaf of Nelumbo nucifera (NN). Through this pathway, NN remove dietary supplementation brought about critical concealment of body weight gain in A/J mice encouraged a HFD [67]. Caffeine, one of the major bioactive segments in oolong tea (Theasinensis) has both a positive charge and a hydrophobic region like that of adrenaline. Caffeine's system of lipolytic activity may be because of its official to the phospholipid phosphate gatherings and the resulting cooperations between the lipase and triglyceride bits of lipid beads, evoking lipolysis [41].

\section{Centrally acting mechanisms}

Weight can likewise be kept up by limiting the admission of sustenance. Numerous items demonstration in a route through their impact on the receptor inside the focal sensory system in this manner building up a feeling of satiety inside the body.

Neuropeptide Signaling Modulators: The dietary admission of people shifts routinely; still weight remains surprisingly stable in many people in light of the fact that by and large vitality admission and use are wonderfully coordinated over extensive stretches of time through the procedure of vitality homeostasis [68,69]. The status of body vitality stores is conveyed to the focal anxious framework by the adiposity-related hormones leptin, insulin, and perhaps chose gastrointestinal (GI) peptides, for example, ghrelin [69]. The arcuate core of the hypothalamus, the essential neurnal flagging site for hunger managing hormones, is chiefly made out of two sorts of neurons: Neuropeptide $\mathrm{Y}$ and its numerous receptors, notwithstanding invigorating melanocortins and other catabolic pathways, the adiposity hormones leptin and insulin restrain anabolic neuropeptides, for example, hypothalamic NPY, and incessant NPY organization intensely builds nourishment admission and body weight. Along these lines, pharmacological bar of NPY flagging is a potential antiobesity technique. Numerous normal hunger suppressants intervene the decreased articulation of hypothalamic neuropeptide Y (NPY) or serum leptin levels [72]. For example, Kim et al. [71], demonstrated that, in HFD-instigated stoutness in rodents, a rough saponin of Korean ginseng viably directed serum leptin and NPY expression in the rodent nerve center. Predetermined number of re-ports were distributed as to connection of regular substances with hunger smothering and craving stimulating particles.

Monoamine Neurotransmitters: Body weight direction through craving control is a multifactorial occasion coming about because of neurological and hormonal interrelationships. A line of proof shows that serotonin, histamine, dopamine, and their related receptor exercises are nearly connected with satiety regulation. Serotonin is a monoaminergic synapse that adjusts various tactile, engine, and conduct forms, acting through a group of no less than fourteen 5-HT receptor subtypes. These receptors may empower analysts to more readily focus on their looks for medications that treat weight through vitality consumption decrease [73]. Operators that demonstration by means of fringe satiety peptide frameworks, change the different hypothalamic neuropeptides' CNS levels, or modify the key CNS hunger monoamine synapses' levels might be reasonable contender for medications that will sup-squeeze craving [74,75]. Green tea and its constituents (catechins, for example, epigallo catechin (EGC) and epigallo catechin gallate (EGCG), have gotten colossal at-tention [76,77], as a few lines of proof recommend EGCG to animate thermogenesis through restraint of the catechol-0-methyltransferase compound engaged with corruption of norepinephrine $[43,57,73,78,79]$.

The probable reasons for obese person to prefer herbal products for weight management

1) Health benefits of weight loss without any side effects.

2) Less demanding than accepted lifestyle changes, such as exercise and diet. 
3) Easily available without a prescription.

4) More easily accepted than a professional consultation with a physician or a nutritionist.

5) $100 \%$ natural origin and perception that natural means safe.

\section{Remarks on available information about herbal treatment for obesity}

For a large number of the home grown weight reduction items, there is little distributed data and there have been no clinical preliminaries or the level of proof is restricted. A portion of the natural items fall under a worthy level of proof viz., clinical preliminaries and with no logical foundation or logical normal.

Gathers accessible clinical preliminary writing on different natural items which have weight lessening effects. Maybe a couple of the items, which experienced clinical preliminary, have noteworthy weight decrease as a general outcome. Alternate items have indicated similarly great results in preclinical investigations however need clinical examinations. There are a few items in the market professed to have surprising weight diminishing impacts, anyway there is no supporting distributed preclinical and clinical information evidences.

\section{An ideal herbal remedy for obesity: a proposal}

Natural items for weight decrease might be viable in the administration of corpulence and related issue. Predictable and safe home grown item for weight decrease is a need of created and creating nations. In our writing overview, home grown items demonstrated potential effects on weight control. In any case, for the greater part of items, more information are expected to evaluate the appropriateness as an enemy of heftiness item. We have endeavored to give notable prospects to a perfect home grown item for the management of corpulence.

1) Ought to cut down the body weight by $10 \%$ over fake treatment in an all-around structured randomized fake treatment con-trolled clinical preliminary.

2) Should demonstrate proof of enhancement of bio checkers like pulse, lipids and glycemia.

3) Ought to have known component of activity.

4) Ought to be institutionalized with bioactive phytochemicals which is/are in charge of hostile to heftiness action.

5) Ought not have any sort of reactions.

\section{Conclusion}

There are a few plants depicted in Ayurveda for weight administration. In any case, up until this point, no methodical and very much planned screening is endeavored to think of a successful natural weight reduction item. A superior comprehension in the current proof constructed science with respect to herbs will additionally control a subjective research in corpulence administration that will pull in the end clients by the compelling advantages. Genuine randomized, twofold blinded, fake treatment controlled clinical preliminaries utilizing natural items will show their potential benefits. Huge weight reduction after fake treatment sub-footing alongside known instrument of activity are required with the end goal to produce conviction among clients as powerful specialist for weight administration.

\section{References}

1. World Health Organization. Obesity. Preventing and Managing the Global Epidemic, Report of a WHO Con- sultation (WHO Technical Report Series 894). WHO. 2000; Ref.: https://goo.gl/mRUXnQ 
2. Worldwide Obesity Trends-Globesity. Ref.: https://goo.gl/WTa5P1

3. Centre for Public Health Excellence at NICE (UK), Na-tional Collaborating Centre for Primary Care (UK) Obesity: The Prevention, Identification, Assessment and Management of Overweight and Obesity in Adults and Children. National Institute for Health and Clinical Ex-cellence (UK) (NICE Clinical Guidelines: 43), 2006; Ref.: https://goo.gl/19FCLw

4. Obesity and Overweight. Fact Sheet No. 311, 2012; Ref.: https://goo.gl/F4qjF5

5. Scheen J. From Obesity to Diabetes: Why, When and Who? Acta Clinica Belgica. (2002; 55: 9- 15. Ref.: https://goo.gl/UN6UZv

6. Felber JP, Golay A. Pathways from Obesity to Diabetes. Int J Obes Relat Metab Disord. 2002; 26: 3945. Ref.: https://goo.gl/YNwmSS

7. Bhatti GR, Qureshi R, Shah SM. Ethnobotany of Calotropis procera with Especial Reference to the People of Nara Desert. Scientific Sindh. 1990; 5: 13-22. Ref.: https://goo.gl/NqPJyy

8. Rahman U, Zaman K. Medicinal Plants with Hypo- glycemic Activity. J Ethnopharmacol. 1989; 2 1-55. Ref.: https://goo.gl/UeXnb1

9. Food and Drug Administration. FDA Briefing Document NDA 21-888 Zimulti (rimonabant) Tablets, 20 mg Sanofi Aventis Advisory Committee. 2007; 2007. Ref.: https://goo.gl/VawXvi

10. Cooke D, Bloom S. The Obesity Pipeline: Current Strategies in the Development of Anti-Obesity Drugs. Nature Reviews Drug Discovery. 2006; 5: 919-931. Ref.: https://goo.gl/bSzCpr

11. Pinder RM, Brogden RN, Sawyer PR, Speight TM, Avery GS. Fenfluramine: A Review of Its Pharmacological Properties and Therapeutic Efficacy in Obesity. Drugs. 1975; 10: 4: 241-323. Ref.: https://goo.gl/M2DQaR

12. Brenot, P. Herve, P. Petitpretz, F. Parent, Duroux P, Simonneau G. Primary Pulmonary Hypertension and Fenfluramine Use. Br Heart J. 1993; 70: 537-541. Ref.: https://goo.gl/sdQeUP

13. Connolly HM, Crary JL, McGoon MD, Hensrud DD, Edwards BS, et al. Valvular Heart Disease Associated with Fenfluramine- Phentermine. N Engl J Med. 1997; 337: 581-588. Ref.: https://goo.gl/XhprfD

14. Swinburn BA, Caterson I, Seidell JC, James WP. Diet, Nutrition and the Prevention of Excess Weight Gain and Obesity. Public Health Nutr. 2004; 7: 123-146. Ref.: https://goo.gl/43KcH9

15. Park JP, Kim JH, Park MK, Yun JW. Potential Agents for Cancer and Obesity Treatment with Herbal Medicines from the Green Garden. Biotechnology and Bioprocess Engineering. 2011; 16: 10651076. Ref.: https://goo.gl/wMLdFJ

16. Amin KA, Nagy MA. Effect of Carnitine and Herbal Mixture Extract on Obesity Induced by High Fat Diet in Rats. Diabetology \& Metabolic Syndrome. 2009; 1: 1-14. Ref.: https://goo.gl/yZnzqn

17. Pickering RP, Grant BF, Chou SP, Compton WM. Are Overweight, Obesity, and Extreme Obe- sity Associated with Psychopathology? Results from the National Epidemiologic Survey on Alcohol and Related Conditions. J Clin Psychiatry. 2007; 68: 998-1009. Ref.: https://goo.gl/SZDXSS

18. Dickerson FB, Brown $\mathrm{CH}$, Kreyenbuhl JA, Fang L, Goldberg RW, et al. Obesity among Individuals with Serious Mental Illness. Acta Psychiatrica Scandinavica. 26;113: 306- 313. Ref.: https://goo.gl/Ns9A1e

19. Simon GE, Von Korff M, Saunders K, Miglioretti DL, Crane PK, et al. Association between Obesity and Psychiatric Disorders in the US Adult Population. Arch Gen Psychiatry. 2006; 63: 824-830. Ref.: https://goo.gl/FqDKiB

20. Aronne LJ. Classification of Obesity and Assessment of Obesity-Related Health Risks. Obesity Research. 2002; 10: 105-115. Ref.: https://goo.gl/z2vGDf

21. Ayensa Jl, Calderon MJ. Psychopathological Comorbidity in Obesity. An Sist Sanit Navar. 2011; 34 253-261. Ref.: https://goo.gl/3EpBgP

22. Britz B, Siegfried W, Ziegler A, Lamertz C, Herpertz-Dahlmann BM, et al. Rates of Psychiatric Disorders in a Clinical Study Group of Adolescents with Extreme Obesity and in Obese Adolescents Ascertained via a Population Based Study. Int J Obes Relat Metab Disord. 2000; 24: 1707-1714. Ref.: https://goo.gl/oYqnLp

23. Lee J, Chae K, Ha J, Park BY, Lee HS, et al. Regulation of Obesity and Lipid Disorders by Herbal Extracts from Morus alba, Melissa officinalis, and Artemisia capillaries in high-fat Diet-Induced Obese Mice. J Ethnopharmacol. 2008; 115: 263-270. Ref.: https://goo.gl/sS1GkG

24. Gosh D. A Botanical Approach to Managing Obesity. University of Wollongong, Wollongong.2009; Ref.: https://goo.gl/mmAqj3 
25. Sharma PV. Dravya Guna Vijnana. Chaukhambha Bharati Academy, Varanasi 1993;.

26. Sharma PC, Yelne MB, Dennis TJ, Joshi A. Database on Medicinal Plants Used in Ayurveda. Central Council for Research in Ayurveda and Siddha, India. 2000; Ref.: https://goo.gl/LK3eME

27. Gogte VM. Medicinal Plants, Part III in Ayurvedic Pharmacology and Therapeutic Uses of Medicinal Plants (Dravyagunavignyan). Bhartiya Vidya Bhavan, Mumbai. 2002; Ref.: https://goo.gl/jy2XZi

28. Misra, Vaisya R. Bhavaprakasha Nigantu. Chau-kamba Sanskrit Sansthan, Varanasi. 2005;

29. Yun JW. Possible Anti-Obesity Therapeutics from Nature A Review. Phytochemistry. 2010; 71: 16251641. Ref.: https://goo.gl/k4TAMa

30. Saper RB, Eisenberg DM, Phillips RS. Common Dietary Supplements for Weight Loss. Am Fam Physician. 2004; 70: 1731- 1738. Ref.: https://goo.gl/Ey9G7A

31. Ioannides-Demos LL, Piccenna L, McNeil JJ. Pharmacotherapies for Obesity: Past, Current, and Future Therapies. J Obes. 2011; Article ID: 179674. Ref.: https://goo.gl/fJHvcV

32. Birari RB, Bhutani KK. Pancreatic Lipase Inhibitors from Natural Sources: Unexplored Potential. Drug Discov Today. 2007; 12: 879-889. Ref.: https://goo.gl/4XBnU9

33. Tsujita T, Takaichi H, Takaku T, Aoyama S, Hiraki J. Antiobesity Action of E-Polylysine, a Potent Inhibitor of Pancreatic Lipase. J Lipid Res. 2006; 47: 1852-1858. Ref.: https://goo.gl/8n6P7L

34. Han LK, Zheng YN, Yoshikawa M, Okuda H, Kimura Y. Anti-Obesity Effects of Chikusetsusaponins Isolated from Panax japonicus Rhizome. BMC Complement Altern Med. 2005; 5: 9. Ref.: https://goo.gl/TcTLJ1

35. Han LK, Xu BJ, Kimura Y, Zheng Yn, Okuda H. Platycodiradix Affects Lipid Metabolism in Mice with High Fat Diet-Induced Obesity. J Nutr. 2000; 130: 2760-2764. Ref.: https://goo.gl/u8xNDX

36. Kishino E, Ito T, Fujita K, Kiuchi Y. A Mixture of the Salacia reticulata (Kotala Himbutu) Aqueous Extract and Cyclodextrin Reduces the Accumulation of Visceral Fat Mass in Mice and Rats with HighFat Diet-Induced Obesity. J Nutr. 2006; 136: 433-439. Ref.: https://goo.gl/8HPtNs

37. Ono Y, Hattori E, Fukaya Y, Imai S, Ohizumi Y. Anti-Obesity Effect of Nelumbo nucifera Leaf Extract in Mice and Rats. J Ethnopharmacol. 2006; 106: 238-244. Ref.: https://goo.gl/ksWRUK

38. Kim HY, Kang MH. Screening of Korean Medicinal Plants for Lipase Inhibitory Activity. Send to Phytother Res. 2005; 19: 359-361. Ref.: https://goo.gl/U5DuUK

39. Moreno DA, Ilic N, Poulev A, Raskin I. Effects of Arachis hypogaea Nutshell Extract on Lipid Metabolic Enzymes and Obesity Parameters. Life Sci. 2006; 78: 2797-2803. Ref.: https://goo.gl/bydeMM

40. Shimoda H, Seki K, Aitani M. Inhibitory Effect of Green Coffee Bean Extract on Fat Accumulation and Body Weight Gain in Mice. BMC Complement Altern Med. 2006; 6: 1-9. Ref.: https://goo.gl/zFsfjS

41. Han LK, Takaku T, Li J, Kimura Y, Okuda H. Anti-Obesity Action of Oolong Tea. Int J Obes Relat Metab Disord. 1999; 23: 98-105. Ref.: https://goo.gl/AEmtKR

42. Nakai M, Fukui Y, Asami S, Toyoda-Ono Y, Iwashita T, et al. Inhibitory Effects of Oolong Tea Polyphenols on Pancreatic Lipase in Vitro. J Agric Food Chem. 2005; 53: 4593-4598. Ref.: https://goo.gl/msrSBV

43. Thielecke F, Boschmann M. The Potential Role of Green Tea Catechins in the Prevention of the Metabolic Syndrome-A Review. Phytochemistry. 209; 70: 11-24. Ref.: https://goo.gl/D1hDPL

44. Kim HK, Della-Fera M, Lin J, Baile CA. Docosahexaenoic Acid Inhibits Adipocyte Differentiation and Induces Apoptosis in 3T3-L1 Preadipocytes. J Nutr. 2006; 136: 2965-2969. Ref.: https://goo.gl/XA44Kv

45. Spiegelman BM, Hu E, Kim JB, Brun R. PPAR Gamma and the Control of Adipogenesis. Biochimistry. 1997; 79: 111-112. Ref.: https://goo.gl/pmaEMo

46. Lombardo YB, Chicco AG. Effects of Dietary Polyunsaturated n-3 Fatty Acids on Dyslipidemia and Insulin Resistance in Rodents and Humans. A Review. J Nutr Biochem. 2006; 17: 1-13. Ref.: https://goo.gl/r8WgY9

47. Murase T, Nagasawa A, Suzuki J, Hase T, Tokimitsu I. Beneficial Effects of Tea Catechins on DietInduced Obesity: Stimulation of Lipid Catabolism in the Liver. Int J Obes Relat Metab Disord. 1999; 26: 1459- 1464. Ref.: https://goo.gl/r9jRjp

48. Kao YH, Hiipakka RA, Liao S. Modulation of Endocrine Systems and Food Intake by Green Tea Epigallocatechin Gallate. Endocrinology. 2000; 141: 980-987. Ref.: https://goo.gl/jaavYv

49. Sayama K, Lin S, Zheng G, Oguni I. Effects of Green Tea on Growth, Food Utilization and Lipid Metabolism in Mice. In Vivo. 2000; 14: 481- 484. Ref.: https://goo.gl/sdMPQJ 
50. Chien PJ, Chen YC, Lu SC, Sheu F. Dietary Flavonoids Suppress Adipogenesis in 3T3-L1 Preadipocytes. Journal of Food and Drug Analysis. 2005 13: 168-175. Ref.: https://goo.gl/9T3Sm7

51. Hargrave KM, Li C, Meyer BJ, Kachman SD, Hartzell DL. Adipose Depletion and Apoptosis Induced by Trans-10, Cis-12 Conjugated Linoleic Acid in Mice. Obes Res. 2002; 10: 1284-1290. Ref.: https://goo.gl/ao4QGr

52. Hwang JT, Park IJ, Shin JI, Lee YK, Lee SK, et al. Genistein, EGCG, and Capsaicin Inhibit Adipocyte Differentiation Process via Activating AMP-Activated Protein Kinase. Biochem Biophys Res Commun. 2002; 338: 694-699. Ref.: https://goo.gl/tr9X1b

53. Hsu CL, Yen GC. Induction of Cell Apoptosis in 3T3-L1 Pre-Adipocytes by Flavonoids Is Associated with Their Antioxidant Activity. Mol Nutr Food Res. 2006; 50: 1072-1079. Ref.: https://goo.gl/Un2F5G

54. Yang JY, Della-Fera MA, Hartzell DL, Nelson-Dooley C, Hausman DB, et al. Esculetin Induces Apoptosis and Inhibits Adipogenesis in 3T3-L1 Cells. Obesity. 2006; 14: 1691-1699. Ref.: https://goo.gl/TBfBUA

55. Yang JY, Della-Fera MA, Rayalam S, Ambati S, Hartzell DL, et al. Enhanced Inhibition of Adipogenesis and Induction of Apoptosis in 3T3- L1 Adipocytes with Combinations of Resveratrol and Quercetin. 2008; Life Sci. 82: 1032-1039. Ref.: https://goo.gl/8g1r1b

56. Picard F, Kurtev M, Chung N, Topark-Ngarm A, Senawong T, et al. Sirt1 Promotes Fat Mobilization in White Adipocytes by Repressing PPAR-Gamma. Nature. 2004; 429: 771-776. Ref.: https://goo.gl/mrU4Hx

57. Rayalam S, Della-Fera MA, Baile CA. Phytochemicals and Regulation of the Adipocyte Life Cycle. The Journal of Nutritional Biochemistry. 2008; 19: 717-726. Ref.: https://goo.gl/eZsJc8

58. Flatt JP. Differences in basal energy expenditure and obesity. Obesity. 2007; 15: 2546-2548. Ref.: https://goo.gl/2XzLHm

59. Redinger RN. Fat Storage and the Biology of Energy Expenditure. Transl Res. 2009; 154: 52-60. Ref.: https://goo.gl/EkS28a

60. Cannon B, Nedergaard J. Brown Adipose Tissue: Function and Physiological Significance. Physiol Rev. 2004; 84: 277-359. Ref.: https://goo.gl/nopuxu

61. Kumar MV, Sunvold GD, Scarpace PJ. Dietary Vitamin a Supplementation in Rats: Suppression of Leptin and Induction of UCP1 mRNA. J Lipid Res. 1999; 40: 824-829. Ref.: https://goo.gl/L6dCMZ

62. Yoon SS, Rhee YH, Lee HJ, Lee EO, Lee MH. Uncoupled Protein 3 and p38 Signal Pathways Are Involved in Anti-Obesity Activity of Solanum tuberosum L. cv. Bora Valley. J Ethnopharmacol. 2008; 118: 396-404. Ref.: https://goo.gl/RCeqkf

63. Dulloo AG. Ephedrine, Xanthines and Prostaglandin-Inhibitors: Actions and Interactions in the Stimulation of Thermogenesis. Int J Obes Relat Metab Disord. 1993; 17: 35-40. Ref.: https://goo.gl/BEHun7

64. Racotta IS, Leblanc J, Richard D. The Effect of Caffeine on Food Intake in Rats: Involvement of Corticotropin Releasing Factor and the Sympatho-Adrenal System. Pharmacol Biochem Behav. 1994; 48: 887-892. Ref.: https://goo.gl/zKSU3T

65. Kawada T, Watanabe T, Takaishi T, Tanaka T, Iwai K. Capsaicin-Induced Beta-Adrenergic Action on Energy Metabolism in Rats: Influence of Capsaicin on Oxy-gen Consumption, the Respiratory Quotient, and Substrate Utilization. Proc Soc Exp Biol Med. 1986; 183: 250-256. Ref.: https://goo.gl/NtGwh6

66. Langin D. Adipose Tissue Lipolysis as a Metabolic Pathway to Define Pharmacological Strategies against Obesity and the Metabolic Syndrome. Pharmacol Res. 2006; 53: 482-491. Ref.: https://goo.gl/zDvENb

67. Ohkoshi E, Miyazaki H, Shindo K, Watanabe H, Yoshida A, et al. Constituents from the Leaf of Nelumbo nucifera Stimulate Lipolysis in the White Adipose Tissue of Mice. Planta Medica. 2007; 73: 1255-1259. Ref.: https://goo.gl/Hofn4m

68. Flier JS. Obesity Wars: Molecular Progress Confronts an Expanding Epidemic. Cell. 2004; 116: $337-$ 350. Ref.: https://goo.gl/EVv9WY

69. Morton GJ, Cummings DE, Baskin DG, Barsh GS, Schwartz MW. Central Nervous System Control of Food Intake and Body Weight. Nature. 2006; 443: 289-295. Ref.: https://goo.gl/gaN2uX

70. Di Pierro F, Menghi AB, Barreca A, Lucarelli M, Calandrelli A. Greenselect Phytosome as an Adjunct to a Low-Calorie Diet for Treatment of Obesity: A Clinical Trial. Altern Med Rev. 2009; 14: 154-160. Ref.: https://goo.gl/xTY4co

71. Kim SO, Yun SJ, Jung B, Lee EH, Hahm DH, et al. Hypolipidemic Effects of Crude Ex- tract of Adlay Seed (Coix lachrymajobi var. Mayuen) in Obesity Rat Fed High Fat Diet: Relations of TNF-Alpha and Leptin mRNA Expressions and Serum Lipid Levels. Life Sci. 2004; 75: 1391-1404. Ref.: https://goo.gl/9BdNp2 
72. Weigle DS. Pharmacological Therapy of Obesity: Past, Present, and Future. The Journal of Clinical Endocrinology and Metabolism. 2003; 88: 2462- 2469. Ref.: https://goo.gl/wuZX99

73. Tecott LH, Sun LM, Akana SF, Strack AM, Lowenstein DH, et al. Eating Disorder and Epilepsy in Mice Lacking 5-HT2c Serotonin Receptors. Nature. 1995; 374: 542-546. Ref.: https://goo.gl/UvMceL

74. Halford JC, Blundell JE. Pharmacology of Appetite Suppression. Prog Drug Res. 2000; 54: 25-58. Ref.: https://goo.gl/B5VCPF

75. Wynne K, Stanley S, McGowan B, Bloom S. Appetite Control. J Endocrinol. 2005; 184: 291-318. Ref.: https://goo.gl/QguvQJ

76. Wolfram S, Wang Y, Thielecke F. Anti-Obesity Effects of Green Tea: From Bedside to Bench. Mol Nutr Food Res. 2006; 50: 176-187. Ref.: https://goo.gl/axTBAV

77. Moon HS, Lee HG, Choi YJ, Kim TG, Cho CS. Proposed Mechanisms of (-)-Epigallocatechin-3- Gallate for Anti-Obesity. Chemico Biological Interactions. 2007; 167: 85-98. Ref.: https://goo.gl/GR7rbX

78. Borchardt RT, Huber JA. Catechol 0-methyl- transferase. 5. Structure-Activity Relationships for Inhibition by Flavonoids. J Med Chem. 1975; 18: 120-122. Ref.: https://goo.gl/CUgfiJ

79. Boschmann M, Thielecke F. The Effects of Epigallocatechin-3-Gallate on Thermogenesis and Fat Oxidation in Obese Men: A Pilot Study. J Am Coll Nutr. 2007; 26: 389-395. Ref.: https://goo.gl/iSyMdW 